\title{
Ruthenium (III) Mediated Oxidation of Thiamine Hydrochloride by PDP in Nitric Acid Medium
}

\author{
Biyyala Sreedhar Rao ${ }^{1}$, M. Anand Rao ${ }^{2}$ \\ Research Scholar, Department of Chemistry, Osmania University, Hyderabad, Telangana, India \\ Professor, Department of Chemistry, Osmania University, Hyderabad, Telangana, India
}

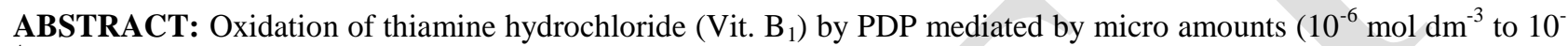
$\left.{ }^{4}\right)$ of $\mathrm{Ru}$ (III) in aqueous nitric acid medium has been studied at $25^{\circ} \mathrm{C}$. The reaction is second order in both PDP and $\mathrm{Ru}$ (III) concentrations. The order with respect to $\mathrm{B}_{1}$ concentration varies first order to zero order as the vitamin $\mathrm{B} 1$ concentration increases, An increase in $\mathrm{HNO}_{3}$ concentration decrease the reation rate. The active species of Oxidant and catalyst are $[\mathrm{PDP}]$ and $\left[\mathrm{Ru}\left(\mathrm{H}_{2} \mathrm{O}\right)_{6}\right]^{3}$ A possible mechanism is proposed and reaction constants involved have been determined. Ruthenium (III) is an efficient catalyst in many redox reactions involving different complexities due to the formation of intermediate complexes, free radicals and multiple oxidation states of ruthenium PDP is a well Known oxidant in acidic media PDP was act as predominant active species in the concentration range $0.30-2.0$ moldm-3 of Nitric acid, but it role has not received much attention so far the oxidation of thiamine hydrochloride with alkaline potassium ferricyanide, hypo iodide, chlorite and $\mathrm{N}$-chloro benzene sulphonamide were studied. The literature survey reveals that there were no report on the oxidation of thiamine hydrochloride by PDP the mechanism may be quite complicated due to the formation of different PDP and Ru (III) Complexes in the form of active complexes in nitric acid medium. Hence, we have investigated the Ru(III) mediated oxidation of vit $\mathrm{B}_{1}$ by PDP in order to understand the behaviour of active species of oxidant and catalyst to propose a suitable mechanism.
\end{abstract}

KEYWORDS: Kinetics, thiamine hydrochloride (vit - $\mathrm{B}_{1}$ ), PDP and Ruthenium (III) catalyst.

\section{INTRODUCTION}

Water soluble vitamins the common feature to most of vitamin B complex have been out lined below cannot be stored in body regular Supply needed most play an essential role in metabolism. Most of them can be sourced from liver and yeast. Most of them are synthesised by colonel bacteria [1-6]. Excess is excreted in urine, no danger of toxic levels, not easy to be stored in the body [7]. Regular supply needed most play an essential role in metabolism. Most of them can be sourced from liver and yeast [8]. Most of them are synthesised by colonal bacteria. Excess is excreted in urine, no danger of toxic levels, not easy to be stored in the body [9-10].

\section{MATERIALS AND METHODS}

Reagent grade chemicals were used double distilled water was used through for the preparation of solutions. The stock solution of the oxidant has obtained by dissolving PDP in $1.0 \mathrm{~mol} \mathrm{dm}{ }^{-3} \mathrm{H}_{2} \mathrm{SO}_{4}$. The solution was standardized by a Known method. A stock solution of thiamine hydrochloride was prepared by dissolving thiamine hydrochloride in distilled water. The Ruthenium (III) stock solution was prepared by dissolving Rucl ${ }_{3}$ in $0.20 \mathrm{~mol} \mathrm{dm}^{-3} \mathrm{Hcl}$ and its concentration was assayed by EDTA titration. The stock solution was diluted as required before use. $\mathrm{KNO}_{3}$ and $\mathrm{HNO}_{3}$ were used to provide the required ionic strength and acidity All Kinetic measurement were carried out under Pseudo first order conditions, where thiamine hydrochloride was in excess over PDP at a constant ionic strength of 1.10 mol $\mathrm{dm}^{-3}$. The reaction was initiated by mixing thermally equilibrated $\left(25 \pm 0.1^{0} \mathrm{C}\right)$. Solutions of PDP and thiamine hydrochloride also containing the required quantity of $\mathrm{HNO}_{3}$ and $\mathrm{Ru}(\mathrm{III})$ catalyst. 


\title{
International Journal of Innovative Research in Science, Engineering and Technology
}

(An ISO 3297: 2007 Certified Organization)

\author{
Vol. 3, Issue 10, October 2014
}

The reaction was following by monitoring the decrease in absorbance of PDP in mixture at $264 \mathrm{~nm}$ in a $1 \mathrm{~cm}$ cell placed in a thermos tatted compartment of avariancary 50 Bio UV. Visible spectrophotometer as a function of time. The application of Beers law under reaction conditions had earlier been verified in the concentration range $1.0 \mathrm{X} 10^{-4}$ to $2.0 \times 10^{-3} \mathrm{~mol} \mathrm{dm}^{-3}$ of PDP at $264 \mathrm{~nm}$ in $1.0 \mathrm{~mol} \mathrm{dm}^{-3} \mathrm{HNO}_{3}$ and water the molar absorpitivity index PDP at $264 \mathrm{~nm}$ was found to be $\sum=7.9 \times 10^{3} \mathrm{~mol}^{-1} \mathrm{~cm}^{-1}$

The Kinetics was followed up to more than $80 \%$ completion of the reaction and good second order kinetics were observed. The second order rate constant $\mathrm{K}_{\mathrm{c}}$ were calculated from the slopes of plots of $\log [\mathrm{PDP}]$ vs time. The $\mathrm{K}_{\mathrm{c}}$ Values were reproducible within ${ }_{ \pm} 5 \%$ and are the average of at least three independent kinetic rules.

\section{MECHANISM}

Ruthenium (III) chloride is known exist in solution in various aqua form. Electronic and spectral studies and ion - exchange properties in aqueous media have shown that it exist as $\left[\mathrm{Ru}\left(\mathrm{H}_{2} \mathrm{O}\right)_{6}\right]^{3+}$
$\mathrm{RuCl}_{3} \times \mathrm{H}_{2} \mathrm{O}+3 \mathrm{HCl}$
$\left[\mathrm{RuCl}_{6}\right]^{3-}+\mathrm{H}_{2} \mathrm{O}+$
$\mathrm{C}_{1}$
$\left[\mathrm{RuCl}_{6}\right]^{3-}+\mathrm{xH}_{2} \mathrm{O}+3 \mathrm{H}^{+}$
$\left[\mathrm{RuCl}_{5}\left(\mathrm{H}_{2} \mathrm{O}\right)\right]^{2-}+\mathrm{Cl}^{-}$
$\mathrm{C}_{2}$

The products, 4-amino -2 methyl Pyrimidine -5- Carboldehyde and 2- (-4 Methyl thia 2 ol- 5yl)- ethanol were confirmed by GC-MS spectra.

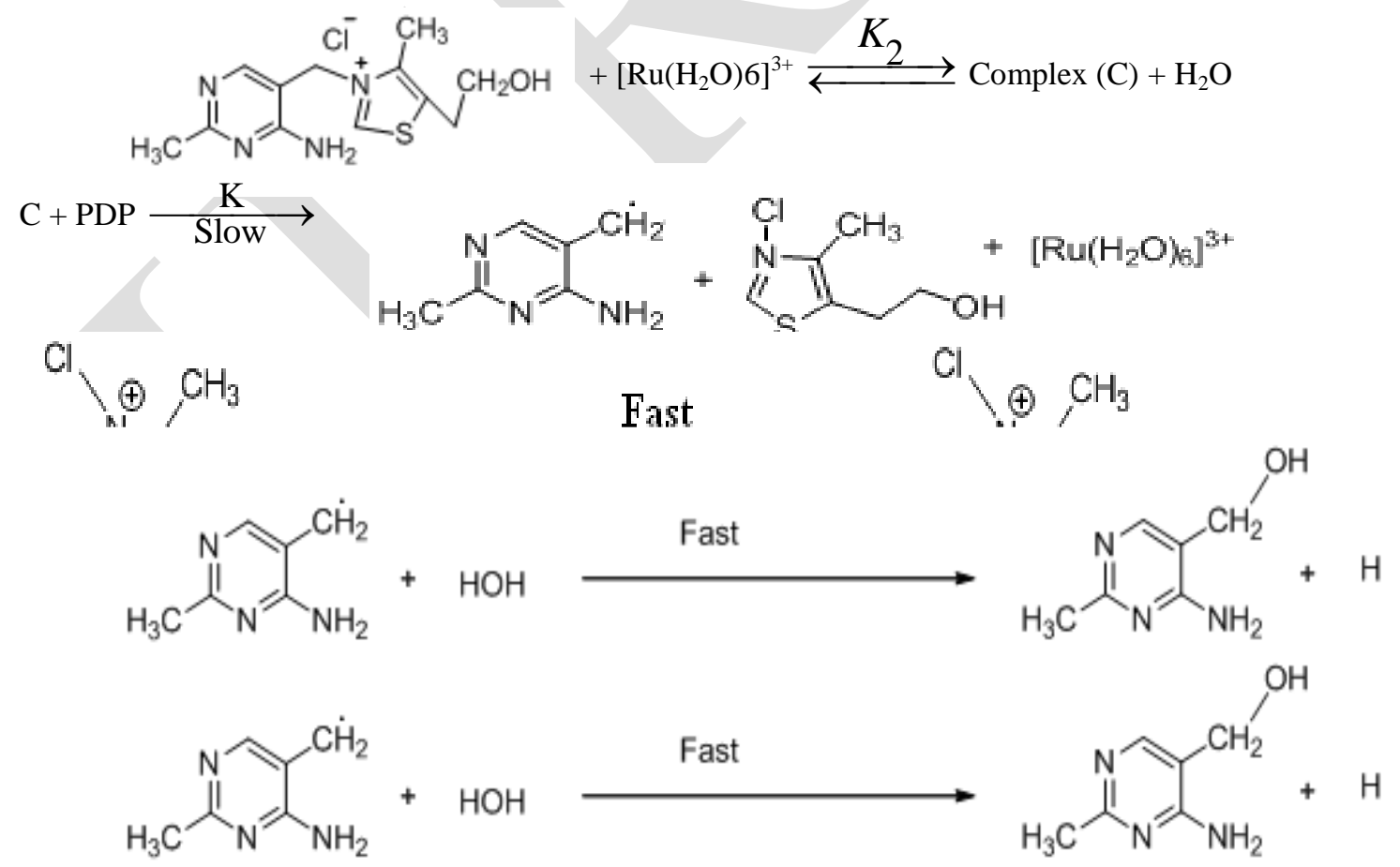




\section{ISSN: 2319-8753}

IIIRSET

International Journal of Innovative Research in Science, Engineering and Technology

(An ISO 3297: 2007 Certified Organization)

Vol. 3, Issue 10, October 2014<smiles>Cc1ncc(CO)c(N)n1</smiles>

The probable structure of the complex<smiles>Cc1ncc(C[n+]2csc(CCO)c2C)c(N)n1</smiles><smiles>C[Te](O)(O)(O)(O)O</smiles>

\section{RESULTS AND DISCUSSION}

$\lambda_{\max }: 264 \mathrm{~nm}$

E of thiamine at $264 \mathrm{~nm}: 7.9 \times 10^{3} \mathrm{dm}^{3} \mathrm{~mol}^{-1} \mathrm{~cm}^{-1}$

[Thiamine]

$$
1 \times 10^{-4 \mathrm{M}}
$$

Stock solution concentration $\quad 2.14 \times 10^{-3 \mathrm{M}}$

$0.47 \mathrm{ml}$ of Thiamine $+9.5 \mathrm{ml}$ of $\mathrm{H}_{2} \mathrm{O}$

Table 1:

Table 2:

\begin{tabular}{|c|c|}
\hline $\begin{array}{c}\text { Irradiation time in } \\
\text { minutes }\end{array}$ & Absorbance \\
\hline 0 & 0.815 \\
0.5 & 0.815 \\
1.0 & 0.815 \\
2.0 & 0.815 \\
4.0 & 0.804 \\
6.0 & 0.804 \\
9.0 & 0.799 \\
14.0 & 0.799 \\
\hline
\end{tabular}

\begin{tabular}{|c|c|}
\hline $\begin{array}{c}\text { Irradiation time in } \\
\text { minutes }\end{array}$ & Absorbance \\
\hline 0 & 0.959 \\
20 & 0.936 \\
40 & 0.917 \\
60 & 0.896 \\
80 & 0.875 \\
100 & 0.86 \\
\hline
\end{tabular}




\section{ISSN: 2319-8753}

\section{International Journal of Innovative Research in Science, Engineering and Technology}

(An ISO 3297: 2007 Certified Organization)

Vol. 3, Issue 10, October 2014
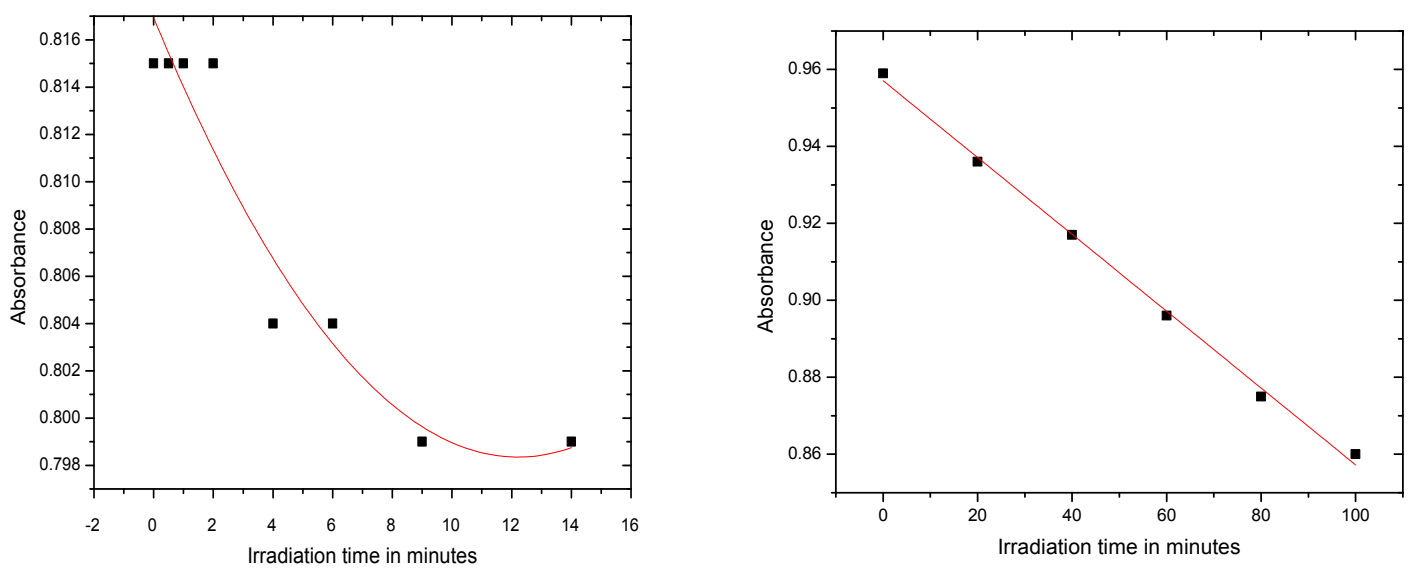

The reaction was followed by measuring the absorbance of thymine at their respective $\lambda_{\max }$ by interrupting the radiation at regular interval of time. The intial rates of thiamine were calculated from the absorbance calculated from the initial rates of oxidation of thiamine and the intensity of light at $264 \mathrm{~nm}$.

\section{Set - I}

Table 3: Effect of [thiamine] in Oxidation of thiamine in presence of PDP
[PDP] $2 \times 10^{-3} \mathrm{M}$
Distance
$14 \mathrm{~cm}$
[Thiamine] - $2 \times 10^{-5} \mathrm{M}$

Intensity of the lamp - $4.5 \times 10^{14}$

$\lambda_{\max } 264 \mathrm{~nm}$

E at $264 \mathrm{~nm}$ - $\quad 7.9 \times 10^{3} \mathrm{dm}^{3} \mathrm{~mol}^{-1} \mathrm{~cm}^{-1}$

[Thiamine] stock in $\mathrm{sol}^{4} \quad-\quad 2.116 \times 10^{-3} \mathrm{M}$

[PDP] stock sol ${ }^{4}$ $6.6 \times 10^{-3} \mathrm{M}$

$0.094 \mathrm{ml}$ of thiamine $+3.03 \mathrm{ml}$ of PDP $+6.87 \mathrm{ml}$ of $\mathrm{H}_{2} \mathrm{O}$

\begin{tabular}{|c|c|}
\hline Irradiation time in minutes & Absorbance \\
\hline 0 & 0.26 \\
0.5 & 0.256 \\
1.0 & 0.253 \\
2 & 0.25 \\
3 & 0.249 \\
5 & 0.243 \\
7 & 0.24 \\
9 & 0.239 \\
12 & 0.223 \\
15 & 0.246 \\
19 & 0.197 \\
24 & 0.178 \\
30 & 0.157 \\
\hline
\end{tabular}


ISSN: 2319-8753

\section{International Journal of Innovative Research in Science, Engineering and Technology}

(An ISO 3297: 2007 Certified Organization)

Vol. 3, Issue 10, October 2014

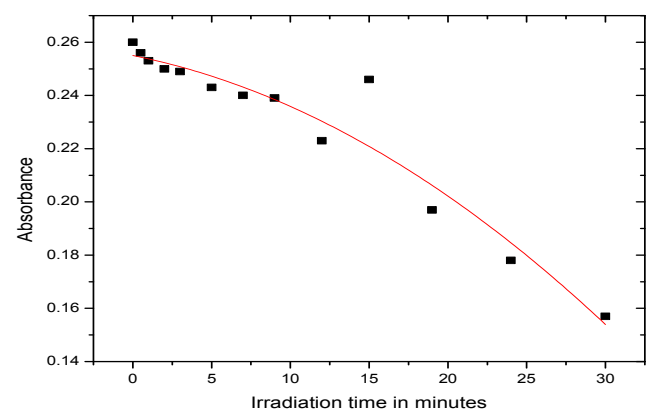

The plot of the absorbance of thiamine verses irradiation of time was found to be polynomial fit and second order reaction. It increases with increasing of reaction time.

\section{Set - II}

Table 4: Effect of [thiamine] in Oxidation of thiamine in presence of PDP
[Thiamine]
$4 \times 10^{-5} \mathrm{M}$

[PDP]

$\lambda_{\max } 264 \mathrm{~nm}$

$2 \times 10^{-3} \mathrm{M}$

$0.094 \mathrm{ml}$ of thiamine $+3.03 \mathrm{ml}$ of $\mathrm{PDP}+6.87 \mathrm{ml}$ of $\mathrm{H}_{2} \mathrm{O}$

\begin{tabular}{|c|c|}
\hline Irradiation time in minutes & Absorbance \\
\hline 0 & 0.375 \\
0.5 & 0.369 \\
1 & 0.363 \\
2 & 0.357 \\
3 & 0.342 \\
5 & 0.324 \\
7 & 0.3 \\
9 & 0.275 \\
12 & 0.253 \\
15 & 0.218 \\
19 & 0.183 \\
\hline
\end{tabular}

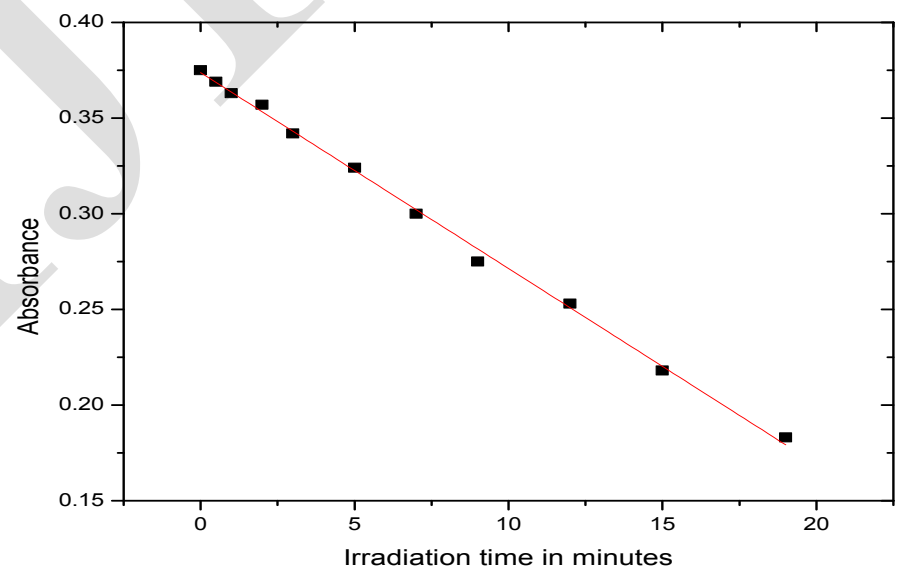




\section{International Journal of Innovative Research in Science, Engineering and Technology}

(An ISO 3297: 2007 Certified Organization)

Vol. 3, Issue 10, October 2014

A plot of absorbance of thiamine verses irradiation of time was found to be linear II order polynomial fit (excluding $2^{\text {nd }}$ minute reading)

$$
\text { Slope }=0.010247
$$

$\mathrm{R}^{2}=0.99998$

\section{Set - III}

Table 5: Effect of [thiamine] in Oxidation of thiamine in presence of PDP
[Thiamine]
$8 \times 10^{-5} \mathrm{M}$
[PDP]
$2 \times 10^{-3} \mathrm{M}$

$\lambda_{\text {max }} 264 \mathrm{~nm}$

$0.38 \mathrm{ml}$ of thiamine $+3.03 \mathrm{ml}$ of PDP $+6.6 \mathrm{ml}$ of $\mathrm{H}_{2} \mathrm{O}$

\begin{tabular}{|c|c|}
\hline Irradiation time in minutes & Absorbance \\
\hline 0 & 0.662 \\
0.5 & 0.654 \\
1 & 0.652 \\
2 & 0.64 \\
3 & 0.625 \\
5 & 0.62 \\
7 & 0.587 \\
9 & 0.565 \\
12 & 0.527 \\
15 & 0.496 \\
19 & 0.442 \\
24 & 0.376 \\
30 & 0.312 \\
\hline
\end{tabular}

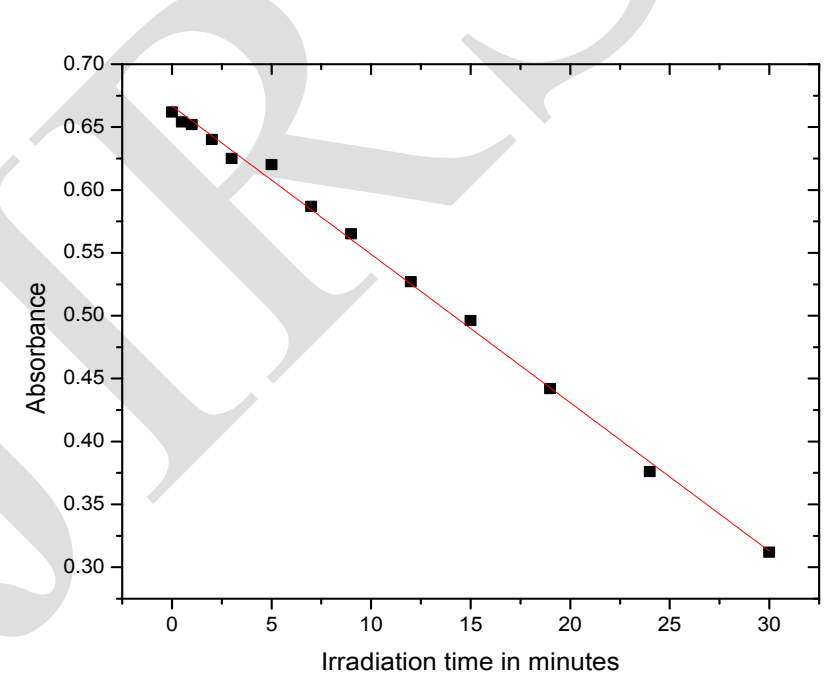

The initial rates and quantum yields of oxidation of thiamine were found to be increase in concentration of thiamine and PDP.

II order polynomial fit (excluding $5^{\text {th }}$ minute reading)

Slope $=0.01247$

$\mathrm{R}^{2}=0.99998$

Set - IV

Table 6: Effect of [thiamine] in Oxidation of thiamine in presence of PDP 
ISSN: 2319-8753

\section{International Journal of Innovative Research in Science, Engineering and Technology}

(An ISO 3297: 2007 Certified Organization)

Vol. 3, Issue 10, October 2014

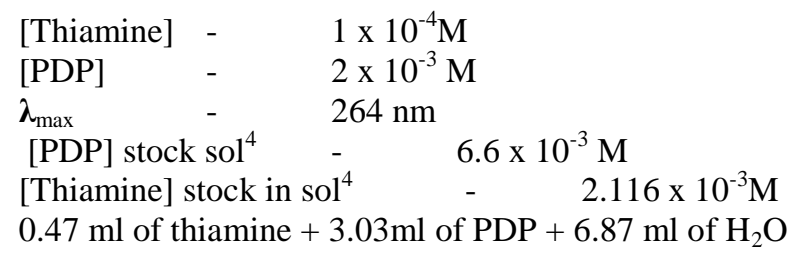

\begin{tabular}{|c|c|}
\hline Irradiation time in minutes & Absorbance \\
\hline 0 & 0.770 \\
0.5 & 0.764 \\
1 & 0.759 \\
2 & 0.754 \\
3 & 0.750 \\
5 & 0.728 \\
7 & 0.712 \\
9 & 0.684 \\
12 & 0.668 \\
15 & 0.629 \\
19 & 0.602 \\
24 & 0.554 \\
30 & 0.498 \\
\hline
\end{tabular}

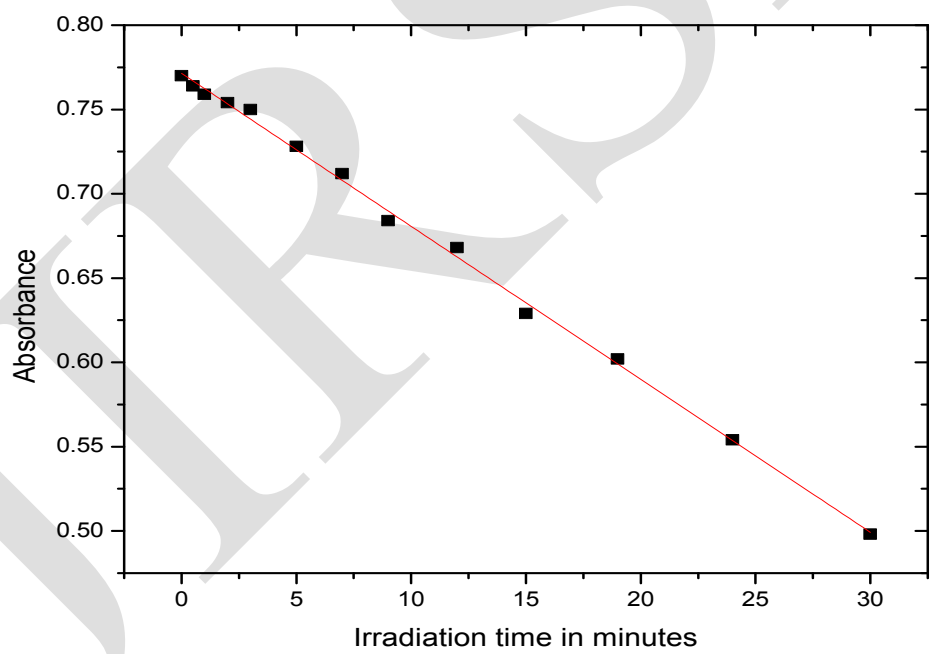

The graph plotted between absorbance of thiamine and irradiation of time in the presence of PDP was found to be linear

II order polynomial fit (excluding $3^{\text {rd }}$ minute reading)

Slope $=0.00815$

$\mathrm{R}^{2}=0.997$

Set - V

Table 7: Effect of [thiamine] in Oxidation of thiamine in presence of PDP

[Thiamine] - $\quad 1.2 \times 10^{-4} \mathrm{M}$

[PDP] - $2 \times 10^{-3} \mathrm{M}$ 
ISSN: 2319-8753

\section{International Journal of Innovative Research in Science, Engineering and Technology}

(An ISO 3297: 2007 Certified Organization)

Vol. 3, Issue 10, October 2014

$\lambda_{\max }{ }^{-} \quad 264 \mathrm{~nm}$

$0.57 \mathrm{ml}$ of thiamine $+3.03 \mathrm{ml}$ of PDP $+6.4 \mathrm{ml}$ of $\mathrm{H}_{2} \mathrm{O}$

\begin{tabular}{|c|c|}
\hline Irradiation time in minutes & Absorbance \\
\hline 0 & 0.928 \\
0.5 & 0.924 \\
1 & 0.921 \\
2 & 0.910 \\
3 & 0.903 \\
5 & 0.879 \\
7 & 0.873 \\
9 & 0.845 \\
12 & 0.830 \\
15 & 0.793 \\
19 & 0.761 \\
24 & 0.712 \\
30 & 0.646 \\
\hline
\end{tabular}

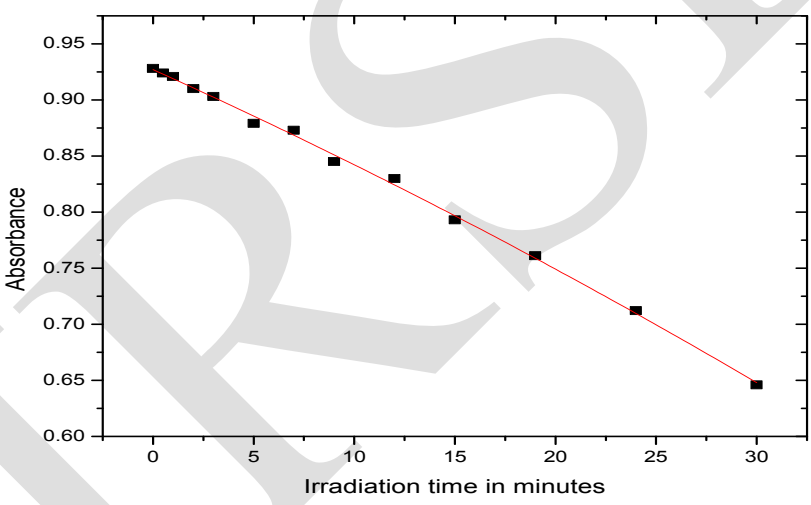

The graph plotted between absorbance of thiamine and irradiation of time in the presence of PDP was found to be linear. The rates of oxidation of thiamine decreases with increasing concentration of thiamine at constant [PDP] .

II order polynomial fit

Slope $=0.0098$

$\mathrm{R}^{2}=0.98995$

Set - I

Table 8: Effect of [PDP] in Oxidation of thiamine in presence of PDP

[Thiamine] - $1 \times 10^{-4} \mathrm{M}$

[PDP] - $1 \times 10^{-3} \mathrm{M}$

$\lambda_{\text {max }}{ }^{-} \quad 264 \mathrm{~nm}$

$0.47 \mathrm{ml}$ of thiamine $+1.51 \mathrm{ml}$ of $\mathrm{PDP}+8.02 \mathrm{ml}$ of $\mathrm{H}_{2} \mathrm{O}$

\begin{tabular}{|c|c|}
\hline Irradiation time in minutes & Absorbance \\
\hline 0 & 0.812 \\
0.5 & 0.809 \\
1 & 0.807 \\
2 & 0.799
\end{tabular}




\section{ISSN: 2319-8753}

IIIRSET

\section{International Journal of Innovative Research in Science, Engineering and Technology}

(An ISO 3297: 2007 Certified Organization)

Vol. 3, Issue 10, October 2014

\begin{tabular}{|c|c|}
3 & 0.793 \\
5 & 0.783 \\
7 & 0.770 \\
9 & 0.767 \\
12 & 0.738 \\
15 & 0.71 \\
19 & 0.697 \\
24 & 0.666 \\
30 & 0.631 \\
\hline
\end{tabular}

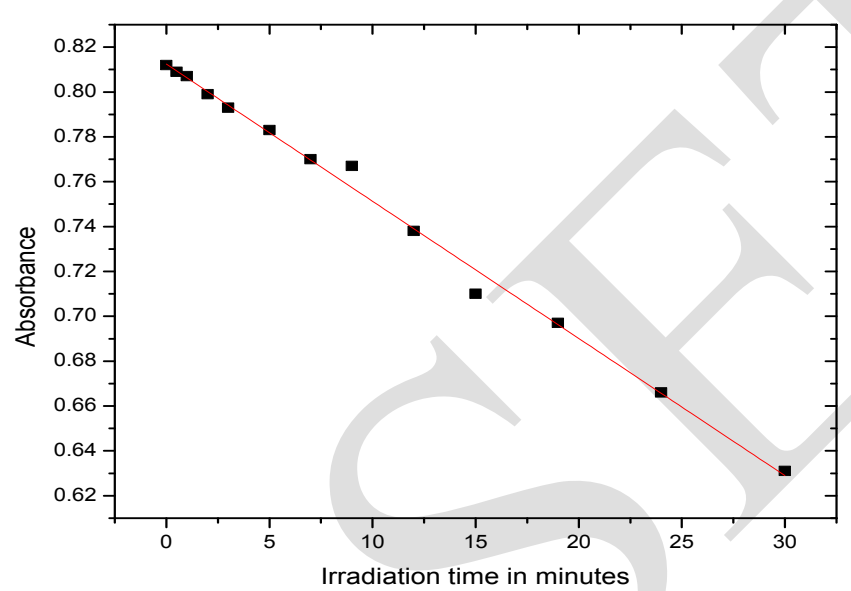

Theeffect of PDP concentration on the oxidation of thiamine increases with increasing o $f$ [PDP] at constant thiamine concentration.

II order polynomial fit (excluding thiamine)

Slope $=0.00703$

$\mathrm{R}^{2}=0.99857$

Set - II

Table 9:Effect of [PDP] in Oxidation of thiamine in presence of PDP

[Thiamine]

[PDP]

$$
1 \times 10^{-4} \mathrm{M}
$$

$2 \times 10^{-3} \mathrm{M}$

$0.47 \mathrm{ml}$ of thiamine $+3.03 \mathrm{ml}$ of $\mathrm{PDP}+6.5 \mathrm{ml}$ of $\mathrm{H}_{2} \mathrm{O}$

\begin{tabular}{|c|c|}
\hline Irradiation time in minutes & Absorbance \\
\hline 0 & 0.793 \\
0.5 & 0.788 \\
1 & 0.783 \\
2 & 0.764 \\
3 & 0.754 \\
5 & 0.733 \\
7 & 0.712 \\
9 & 0.693 \\
12 & 0.650 \\
15 & 0.620 \\
19 & 0.573 \\
24 & 0.516 \\
30 & 0.450 \\
\hline
\end{tabular}




\section{International Journal of Innovative Research in Science, Engineering and Technology}

(An ISO 3297: 2007 Certified Organization)

Vol. 3, Issue 10, October 2014

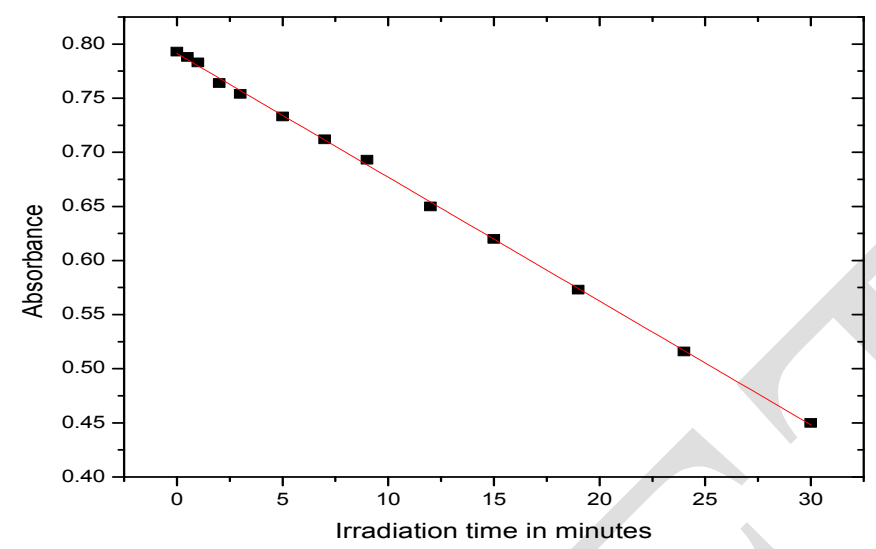

Theeffect of PDP concentration on the oxidation of thiamine increases with increasing o $\mathrm{f}$ [PDP] at constant thiamine concentration.

II ${ }^{\text {nd }}$ order polynomial fit

Slope $=0.014$

$\mathrm{R}^{2}=0.99628$

Set - III

Table 10: Effect of [PDP] in Oxidation of thiamine in presence of PDP

[Thiamine]

[PDP]

$1 \times 10^{-4} \mathrm{M}$

$2 \times 10^{-3} \mathrm{M}$

$0.47 \mathrm{ml}$ of thiamine $+3.03 \mathrm{ml}$ of $\mathrm{PDP}+6.5 \mathrm{ml}$ of $\mathrm{H}_{2} \mathrm{O}$

\begin{tabular}{|c|c|}
\hline Irradiation time in minutes & Absorbance \\
\hline 0 & 0.842 \\
0.5 & 0.842 \\
1 & 0.833 \\
2 & 0.821 \\
3 & 0.818 \\
5 & 0.801 \\
7 & 0.772 \\
9 & 0.754 \\
12 & 0.721 \\
15 & 0.69 \\
19 & 0.64 \\
24 & 0.587 \\
30 & 0.524 \\
\hline
\end{tabular}


ISSN: 2319-8753

IIIRSET

\section{International Journal of Innovative Research in Science, Engineering and Technology}

(An ISO 3297: 2007 Certified Organization)

Vol. 3, Issue 10, October 2014

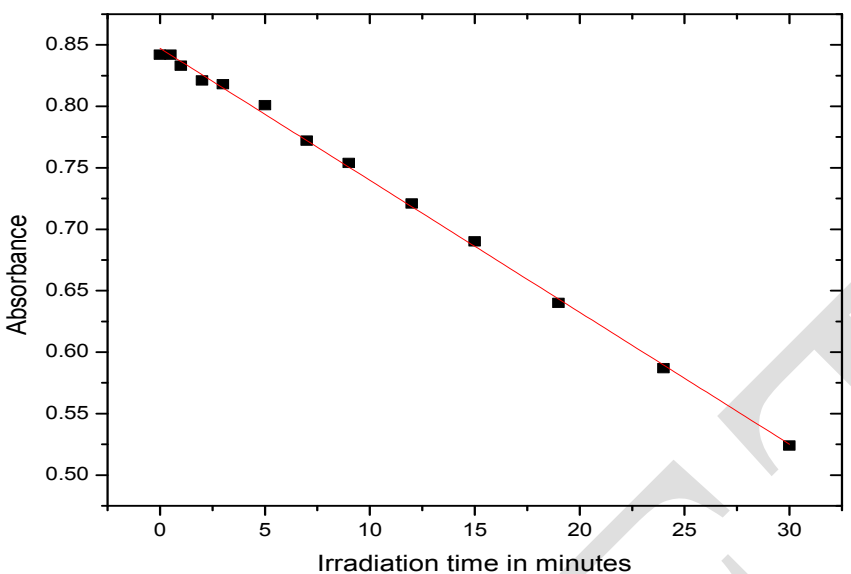

The effect of PDP concentration on the oxidation of thiamine increases with increasing o $\mathrm{f}$ [PDP] at constant thiamine concentration.

II ${ }^{\text {nd }}$ order polynomial fit

Slope $=0.107$

$\mathrm{R}^{2}=0.99971$

Set - I

Table 11: Effect of light intensity on Oxidation of thiamine in presence of PDP

[Thiamine] - $\quad 1 \times 10^{-4} \mathrm{M}$

[PDP] - $2 \times 10^{-3} \mathrm{M}$

Distance - $\quad 14 \mathrm{~cm}$

Intensity - $\quad 4.5 \times 10^{4} \mathrm{q} / \mathrm{s}$

$0.47 \mathrm{ml}$ of thiamine $+3.03 \mathrm{ml}$ of $\mathrm{PDP}+6.5 \mathrm{ml}$ of $\mathrm{H}_{2} \mathrm{O}$

\begin{tabular}{|c|c|}
\hline Irradiation time in minutes & Absorbance \\
\hline 0 & 0.842 \\
0.5 & 0.842 \\
1 & 0.833 \\
2 & 0.821 \\
3 & 0.818 \\
5 & 0.801 \\
7 & 0.772 \\
9 & 0.754 \\
12 & 0.721 \\
15 & 0.69 \\
19 & 0.64 \\
30 & 0.587 \\
\hline
\end{tabular}


ISSN: 2319-8753

\section{International Journal of Innovative Research in Science, Engineering and Technology}

(An ISO 3297: 2007 Certified Organization)

Vol. 3, Issue 10, October 2014

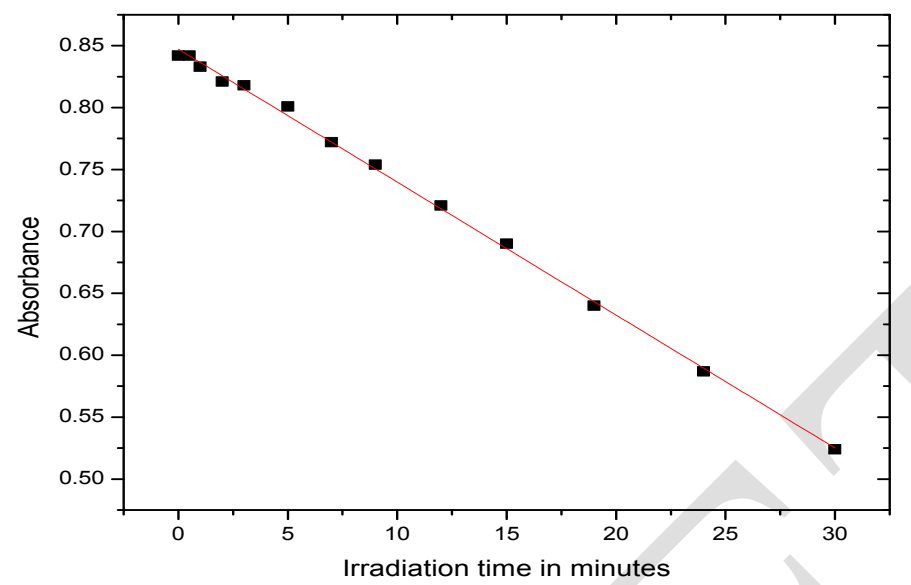

The effect of light intensity on the oxidation of thiamine was studied at constant thiamine concentration and constant PDP concentration and it was found the rates of oxidation of thiamine increases with increase in light intensity. While quantum yields of thiamine were independent of light intensity.

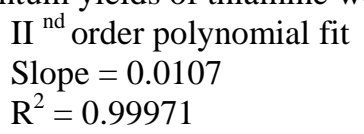

Set - II

Table 12: Effect of light intensity on Oxidation of thiamine in presence of PDP

[Thiamine] - $\quad 1 \times 10^{-4} \mathrm{M}$

[PDP] - $2 \times 10^{-3} \mathrm{M}$

Distance - $21 \mathrm{~cm}$

\begin{tabular}{|c|c|}
\hline Irradiation time in minutes & Absorbance \\
\hline 0 & 0.801 \\
0.5 & 0.796 \\
1 & 0.796 \\
2 & 0.793 \\
3 & 0.793 \\
5 & 0.78 \\
7 & 0.77 \\
9 & 0.759 \\
12 & 0.747 \\
15 & 0.733 \\
24 & 0.719 \\
30 & 0.699 \\
\hline
\end{tabular}


ISSN: 2319-8753

\section{International Journal of Innovative Research in Science, Engineering and Technology}

(An ISO 3297: 2007 Certified Organization)

Vol. 3, Issue 10, October 2014

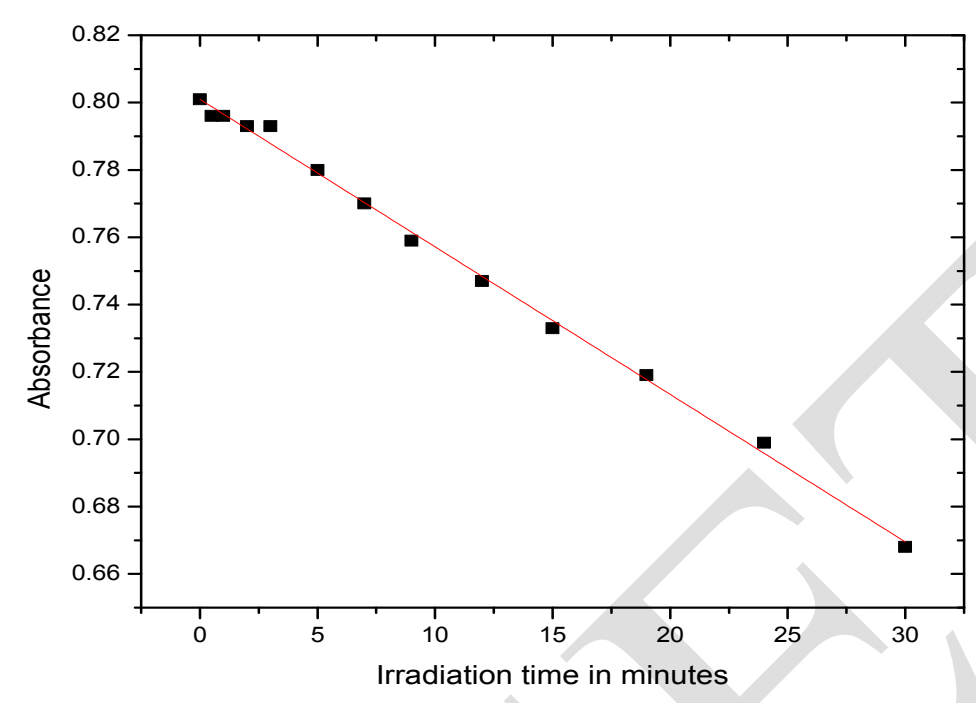

The effect of light intensity on the oxidation of thiamine was studied at constant thiamine concentration and constant PDP concentration and it was found the rates of oxidation of thiamine increases with increase in light intensity. While quantum yields of thiamine were independent of light intensity.

II order polynomial fit

Slope $=0.00491$

$\mathrm{R}^{2}=0.99828$

Set - II

Table 13: Effect of light intensity on Oxidation of thiamine in presence of PDP
[Thiamine] - $1 \times 10^{-4} \mathrm{M}$
[PDP] - $2 \times 10^{-3} \mathrm{M}$
Distance - $28 \mathrm{~cm}$

\begin{tabular}{|c|c|}
\hline Irradiation time in minutes & Absorbance \\
\hline 0 & 0.793 \\
0.5 & 0.793 \\
1 & 0.793 \\
3 & 0.793 \\
5 & 0.788 \\
9 & 0.783 \\
12 & 0.775 \\
15 & 0.764 \\
19 & 0.759 \\
24 & 0.75 \\
30 & 0.733 \\
45 & 0.722 \\
50 & 0.708 \\
\hline
\end{tabular}


ISSN: 2319-8753

IIIRSET

\section{International Journal of Innovative Research in Science, Engineering and Technology}

(An ISO 3297: 2007 Certified Organization)

Vol. 3, Issue 10, October 2014

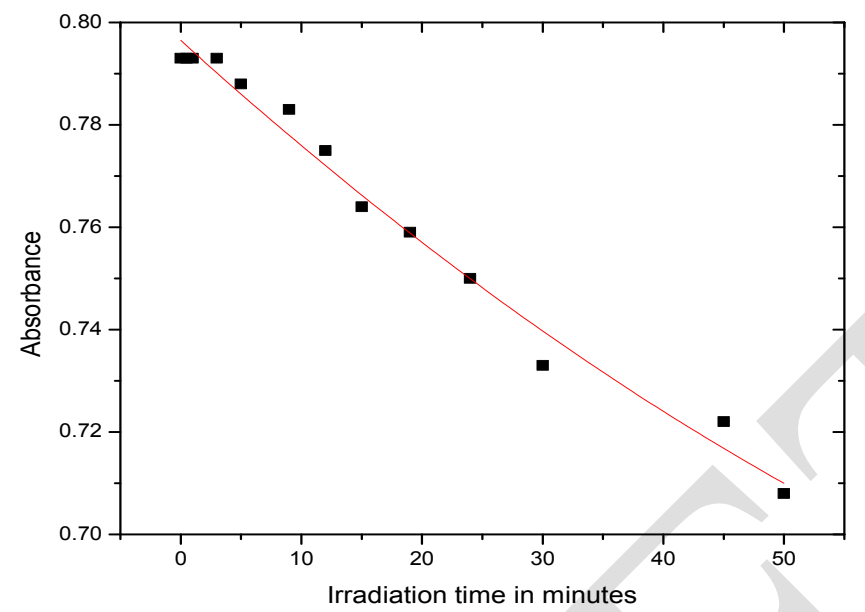

The quantum yields of oxidation of thiamine in the presence PDP were calculated from the initial rates and light intensity at $264 \mathrm{~nm}$ and were found to decreases with increase in [thiamine] at constant [PDP] and [Ru].

II order polynomial fit

Slope $=0.00220$

$\mathrm{R}^{2}=0.97728$

\section{CONCLUSION}

Different reaction mixtures with different sets of concentrations of reactants, where PDP was in excess over thiamine hydrochloride $\left(\right.$ Vit. $\left.\mathrm{B}_{1}\right)$ at constant ionic strength acidity and concentration of catalyst was Kept for $8 \mathrm{~h}$ at room temperature in an inset atmosphere. The un reacted PDP concentration was assayed by measuring the absorbance at $264 \mathrm{~nm}$ the products were identified and confirmed by UV - Vis, I.R, G.C - Ms and NMR Spectra. The reaction orders were determined from the slopes of irradiation of time vs absorbance plots by varying the concentration of PDP and thiamine hydrochloride. The rate of reactions was measured at different temperatures, $25^{\circ}, 30^{\circ}, 35^{\circ}, 45^{\circ} \mathrm{C}$ under varying acid and thiamine hydrochloride concentration. The rates were found to increase with increasing temperature. The rates and quantum yields of oxidation of thiamine increased with increase in concentration of Thiamine. Effect of light intensity on oxidation of thiamine in presence of PDP observed the graph plotted between irradiation of time and absorbance.

\section{REFERENCES}

[1] Charitha, Lingareddy; Adinarayana, Mundra, Kinetics of oxidation of thymine by $t$-butoxyl radical — Protection and repair by caffeic acid, IJC-A, Vol.45,11, 2006,

[2] Stepuro, A. Yu. Oparin, V. I. Stsiapura, S. A. Maskevich, V. Yu. Titov, Oxidation of thiamine on reaction with nitrogen dioxide generated by ferric myoglobin and hemoglobin in the presence of nitrite and hydrogen peroxide Biochemistry (Moscow), Vol. 77, No. 1, pp. 41552012.

[3] Davis, K. L., Martin, E., Turko, I. V., and Murad, F. Annu. Rev. Pharmacol. Toxicol., 41, 203236, 2001.

[4] Schopfer, F. J., Baker, P. R., and Freeman, B. A. Trends Biochem Sci., 28, 646654, 2003.

[5] Kaur, H., and Halliwell, B. FEBS Lett., 350, 912. Torre, D., Ferrario, G., Speranza, F., Orani, A., Fiori, G.P., and Zeroli, C. (1996) J. Clin. Pathol., 49, 574576, 1994.

[6] Qury, T. D., Tatro, L., Ghio, A. J., and Piantadosi, C. A. Free Radical Res., 23, 537547, 1995.

[7] Sampson, M. B., Ye, Y.Z., Rosen, H., and Beckman, J. S. Arch. Biochem. Biophys., 356, 207213, 1998.

[8] Zweier, J., Wang, P., Samouilov, A., and Kuppusamy, P. Nature Med., 1, 804809, 1995.

[9] Stepuro, I. I., Chaikovskaya, N. A., Solodunov, A. A., and Artsukevich, A. N. Biochemistry (Moscow), 62, 960, 966, 1997.

[10] Gladwin, M. T., Shelhamer, J. H., Schechter, A. N., Pease, Fye, M. E., Waclawiw, M. A., Panza, J. A., Ognibene, F. P., Cannon III, R. O. Proc. Natl. Acad. Sci. USA, 97, 1148211487, 2000. 